\title{
Effect of Lactobacillus spp. on adhesion, invasion, and translocation of Campylobacter jejuni in chicken and pig small-intestinal epithelial cell lines
}

\author{
Maja Šikić Pogačar ${ }^{1 *}$ (D), Tomaž Langerholc², Dušanka Mičetić-Turk1, Sonja Smole Možina ${ }^{3}$ and Anja Klančnik ${ }^{3}$
}

\begin{abstract}
Background: Campylobacter spp. are a major cause of bacterial food-borne diarrhoeal disease. This mainly arises through contamination of meat products during processing. For infection, Campylobacter spp. must adhere to epithelial cells of the mucus layer, survive conditions of the gastrointestinal tract, and colonise the intestine of the host. Addition of probiotic bacteria might promote competitive adhesion to epithelial cells, consequently reducing Campylobacter jejuni colonisation. Effect of Lactobacillus spp. (PCS20, PCS22, PCS25, LGG, PCK9) on C. jejuni adhesion, invasion and translocation in pig (PSI Cl.1) and chicken (B1OXI) small-intestine cell lines, as well as pig enterocytes (CLAB) was investigated.
\end{abstract}

Results: Overall, in competitive adhesion assays with PSI cl.1 and CLAB cell monolayers, the addition of Lactobacillus spp. reduced C. jejuni adherence to the cell surface, and negatively affected the C. jejuni invasion. Interestingly, Lactobacillus spp. significantly impaired C. jejuni adhesion in three-dimensional functional PSI cl.1 and B1OXI cell models. Also, C. jejuni did not translocate across PSI cl.1 and B1OXI cell monolayers when co-incubated with probiotics. Among selected probiotics, Lactobacillus rhamnosus LGG was the strain that reduced adhesion efficacy of $C$. jejuni most significantly under co-culture conditions.

Conclusion: The addition of Lactobacillus spp. to feed additives in livestock nutrition might be an effective novel strategy that targets Campylobacter adhesion to epithelial cells, and thus prevents colonisation, reduces the transmission, and finally lowers the incidence of human campylobacteriosis.

Keywords: Campylobacter jejuni, Lactobacillus spp., Chicken and pig cell line, Adhesion, Invasion, Translocation

\section{Background}

Campylobacter jejuni is the most reported food-borne pathogen in human gastrointestinal infections over last decade [1]. C. jejuni are frequently found in the gastrointestinal tract of healthy animals that are destined for human consumption, especially chickens, which naturally harbour Campylobacter spp. in their gastrointestinal tracts $[1-3]$.

The intestinal epithelium of the host represents the first barrier against this food-borne pathogen and is supported by the response of the mucosal immune system

\footnotetext{
* Correspondence: maja_sikic@yahoo.com.au

${ }^{1}$ Faculty of Medicine, University of Maribor, 2000 Maribor, Slovenia

Full list of author information is available at the end of the article
}

that is tightly connected with the gastrointestinal barrier. However, to establish an infection, Campylobacter spp. first adhere to and persist in the mucus layer that covers the intestinal epithelium, and thus survive the adverse conditions of the gastrointestinal tract, to finally colonise the jejunum and ileum of the host $[4,5]$. Adhesion to epithelial cells of the animal gastrointestinal tract is thus the first and important step for successful colonisation. This further promotes transmission of $C$. jejuni to humans, which occurs mainly through handling and consumption of contaminated poultry and pork meat products during slaughter and carcass processing $[2,6$, 7]. It is therefore imperative to reduce the prevalence and colonisation of Campylobacter at the farm level,

C The Author(s). 2020 Open Access This article is distributed under the terms of the Creative Commons Attribution 4.0 International License (http://creativecommons.org/licenses/by/4.0/), which permits unrestricted use, distribution, and reproduction in any medium, provided you give appropriate credit to the original author(s) and the source, provide a link to the Creative Commons license, and indicate if changes were made. The Creative Commons Public Domain Dedication waiver (http://creativecommons.org/publicdomain/zero/1.0/) applies to the data made available in this article, unless otherwise stated. 
where good hygiene and biosecurity practices are not sufficient [8]. In particular, the control of Campylobacter spp. in poultry is the most important concern for consumers [1, 9]. Importantly, this needs to be achieved without increased use of antibiotics and for that reason, alternative strategies for the reduction of colonisation of Campylobacter spp. are urgently needed. In this context, an effective approach that targets Campylobacter adhesion to the intestinal mucus will prevent colonisation and thus reduce the bacterial load of Campylobacter spp. in live animals. The consequent reduced transmission from animal carcasses to humans will thus lower the risk to consumers.

Several strategies with limited efficacy have been applied to reduce the burden of Campylobacter spp. in the intestine of pig and poultry including vaccination, passive immunisation, bacteriophage therapy, bacteriocin application, organic acids, and medium chain fatty acids [1, 9-11]. On the other hand, probiotic bacteria can have high affinity for adherence to the mucosal wall, where they promote the integrity of the healthy functioning of the gastrointestinal barrier by decreasing paracellular permeability through strengthening the tight junctions [12-14]. Thus, the selected probiotic strains could offer an alternative method to reduce Campylobacter spp. load in animal farming.

The protective role of the probiotic bacteria against pathogens mostly lies in their competition for adhesion sites and nutrients, and their production of antibacterial substances [15]. With the emergence of serious antibiotic resistance in livestock breeding, farmers are considering the use of probiotics as feed additives in livestock nutrition, as this might induce immune system function and confer health benefits to the host animal [16-18]. Higher production of volatile fatty acids in the large intestine contributes to good Lactobacillus sp. growth in the caecum of pigs, that enhance digestion, improve nutrient absorption in the intestine and consequently increase the feed efficiency $[17,19]$.

However, host-pathogen-probiotic interactions must be defined before the application of any alternative strategy for pathogen reduction at the farm level, as defined by the regulatory agencies in many countries, including the European Union [7]. To avoid unnecessary usage of animals in the research projects along with ethical considerations, many highly differentiated cell lines were developed with the aim to establish comparable functionality to their in vivo counterparts. In contrast to the more expensive animal trials, cell-line models are cost effective and allow massive screening. In addition, cell-line models are in line with the three $\mathrm{R}$ paradigms meaning to Reduce, Refine, and Replace [20]. Despite intense focus on probiotic research in literature, the Campylobacter- host cell-probiotic interaction mechanisms are not yet completely understood. C. jejuni is able to adhere to the gut epithelium, induce cell death, and disrupt mucosal barrier function. Although Lactobacillus spp. can modulate epithelial cell invasion by $C$. jejuni, how this is achieved is still not well understood [15, 21, 22]. A few studies have reported reduced C. jejuni adhesion when such probiotics had colonised the mucus, which has been studied in models with mucin [23] and with chicken intestinal mucus [24, 25]. However, the majority of in vitro models that have been used to investigate anti-Campylobacter activities of probiotics had been based on human cervical or intestinal cell lines [26]. The use of functional pig and chicken cell line models of non-tumorous origins may provide a better model if the goal is to identify probiotics that can be used in livestock nutrition. However, to the best of our knowledge, there have not been any in vitro studies that have evaluated the efficacy of Lactobacillus spp. for prevention of C. jejuni adhesion and invasion of pig and chicken intestinal epithelium.

Thus in our study we have used Lactobacillus spp. to modulate Campylobacter host-cell interactions using pig and chicken small-intestine cell-line models in vitro. The aim was to prevent and/or reduce the C. jejuni $\mathrm{K} 49 / 4$ adhesion, invasion and translocation through competitive adhesion with $L$. plantarum (PCS20, PCS22, PCS25), L. rhamnosus LGG and L. plantarum (PCK9), using pig (PSI cl.1) and chicken (B1OXI) epithelial small intestine cells, and pig enterocytes (CLAB cells).

\section{Results}

\section{Cytotoxicity}

The co-incubation of the probiotic bacteria L. plantarum (PCS20, PCS22, PCS25), L. rhamnosus LGG and L. plantarum PCK $\left(1 \times 10^{8} \mathrm{CFU} / \mathrm{mL}\right)$ with the pig PSI cl.1, chicken B1OXI, and pig CLAB epithelial cell monolayers did not show any cytotoxic effects after $24 \mathrm{~h}$. The viability of PSI cl.1, B1OXI and CLAB cells ranged from 90 to $100 \%$ when the probiotic bacteria were added, compared to non-treated monolayers (Fig. 1a). As expected, the co-incubation of pathogenic C. jejuni K49/4 with the PSI cl.1, B1OXI and CLAB cells resulted in cytotoxic effects, with disruption of the monolayers, when compared to untreated cells. This was most significant for the PSI cl.1 cells, which showed only $40 \%$ viability after $24 \mathrm{~h}$ (Fig. 1a), thus indicating that the PSI cl.1 cells were the most sensitive cells to $C$. jejuni infection. Addition of the probiotic strains in combination with $C$. jejuni showed protected effects for the PSI cl.1, B1OXI and CLAB cells viability. The viability of B1OXI and CLAB cells remained $>90 \%$ after the co- 


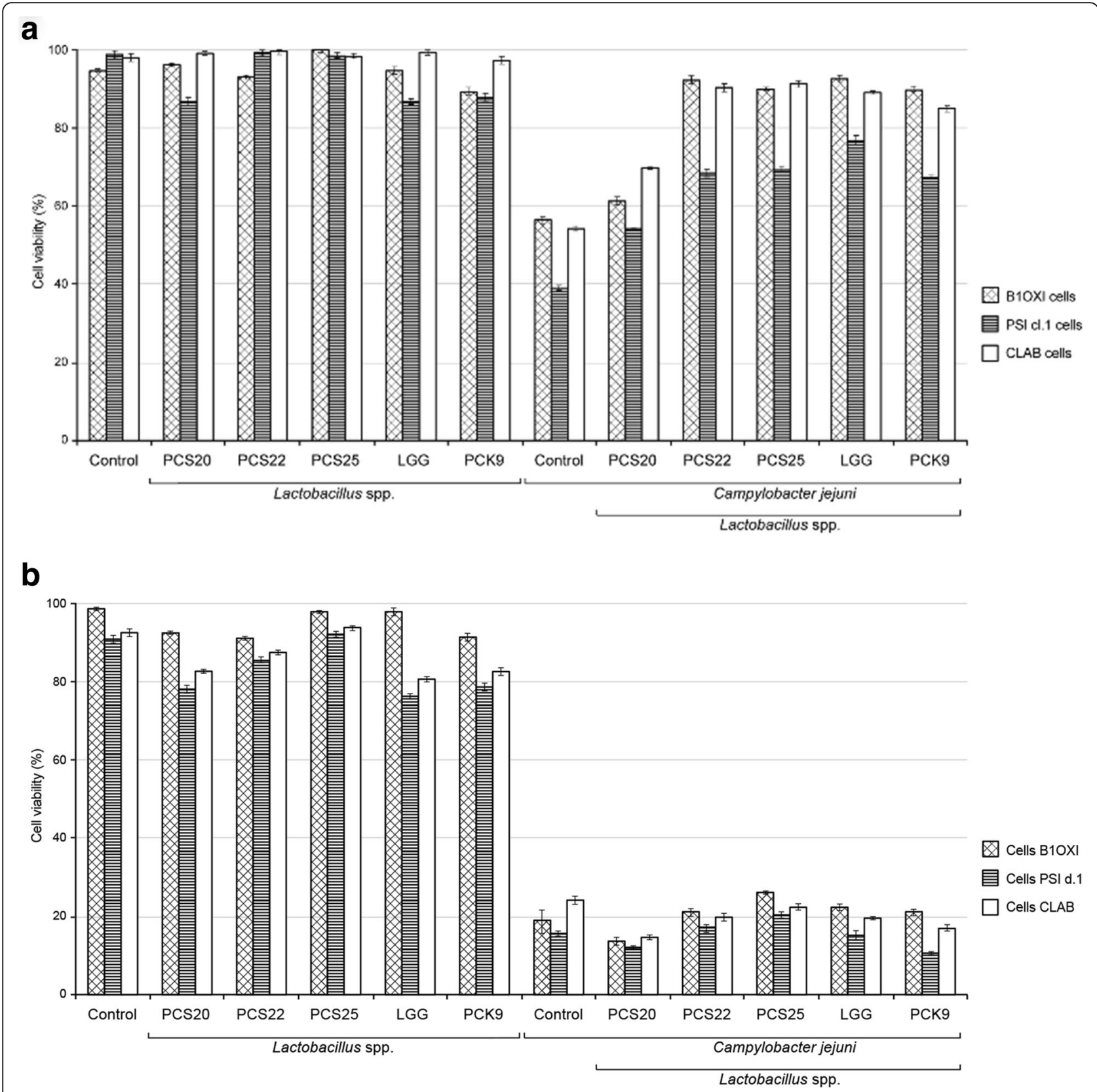

Fig. 1 MTT proliferation assay. PSI C1.1, B1OXI and CLAB cells were seeded at $6 \times 10^{5}$ cells/ well. As confluent monolayers, the cells were exposed to the selected probiotic bacteria $\left(1 \times 10^{8} \mathrm{CFU} / \mathrm{mL}\right)$ or to the combination of the probiotic bacteria $\left(1 \times 10^{8} \mathrm{CFU} / \mathrm{mL}\right)$ and C. jejuni $\left(2 \times 10^{8} \mathrm{CFU} /\right.$ $\mathrm{mL})$, for $24 \mathrm{~h}(\mathbf{a})$ and $48 \mathrm{~h}(\mathbf{b})$. Error bars indicate the standard deviation from at least three independent experiments. Data are expressed as \% cell survival, compared to the control

incubations of the combinations of the PCS22, PCS25, LGG and PCK9 bacteria with C. jejuni for $24 \mathrm{~h}$ (Fig. 1a), and more than $80 \%$ after $48 \mathrm{~h}$ (Fig. 1b). However, these combinations of the probiotic strains and C. jejuni showed greater detrimental effects with the PSI cl.1 cells, resulting in only 50 to $70 \%$ cell viability after $24 \mathrm{~h}$ of coincubation (Fig. 1a). The viability of B1OXI, PSI cl1 and CLAB was even more reduced after $48 \mathrm{~h}$ of coincubation, with less than $20 \%$ cell viability (Fig. 1b).

\section{Campylobacter jejuni adhesion and invasion in cell monolayers}

The efficiency of the Lactobacillus strains PCS20, PCS22, PCS25, LGG and PCK9 was determined in terms of impairment of competitive C. jejuni K49/4 adhesion and invasion to pig PSI cl.1 and CLAB enterocytes using the non-polarised cell models (Fig. 2). L. rhamnosus LGG showed the greatest reduction of $C$. jejuni adherence and invasion to the PSI cl.1 and CLAB cell 

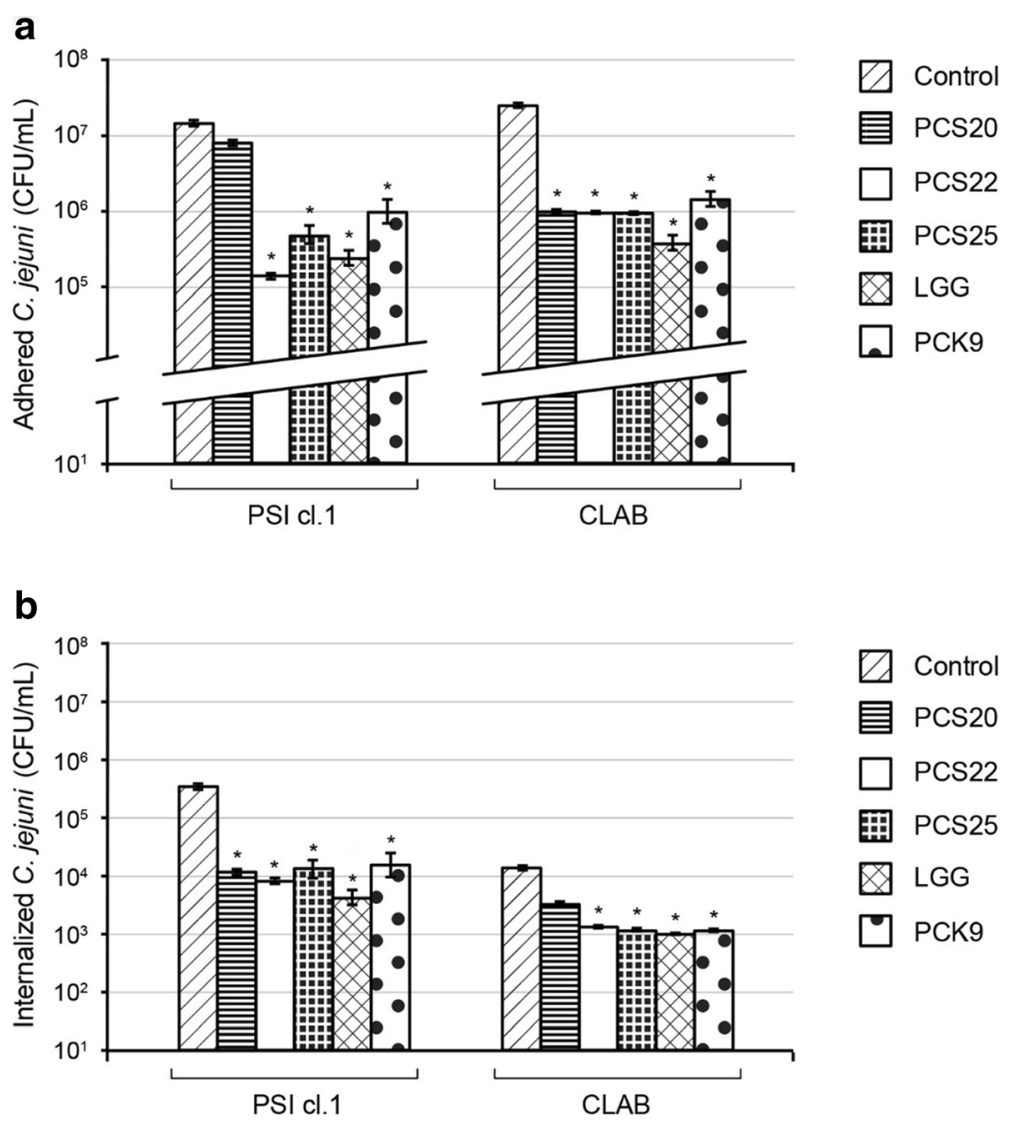

Fig. 2 Campylobacter jejuni $\left(2 \times 10^{8} \mathrm{CFU} / \mathrm{mL}\right)$ adhesion to (a) and invasion into (b) non polarised PSI cl.1 and CLAB pig intestine epithelial cells, after $2 \mathrm{~h}$ co-culture without or with probiotic bacteria (as indicated; concentration of $1 \times 10^{8} \mathrm{CFU} / \mathrm{mL}$ ). Error bars indicate the standard deviation from at least three independent experiments. Data are expressed as means $\pm \mathrm{SD}$. ${ }^{*} P \leq 0.01$, versus control

monolayers. Here, the control adhesion of the starting C. jejuni inoculum was $2 \%$, which was reduced approximately to $0.02 \%$ by $L$. rhamnosus LGG in both, PSI cl.1 and CLAB cell models (Fig. 2a). Additionally, L. plantarum PCS25 reduced this control C. jejuni adhesion on PSI cl. 1 cells to $0.04 \%$ and PCS22 to only $0.01 \%$ (Fig. 2a). Despite slightly higher C. jejuni adhesion to CLAB cells (Fig. 2a), the $C$. jejuni invasion into these cells was lower when compared to the PSI cl. 1 cells (Fig. 2b). As shown in Fig. $2 \mathrm{~b},<0.1 \%$ of the $C$. jejuni cells invaded the PSI cl.1 cells, and approximately $0.001 \%$ invaded the CLAB cells. The results further demonstrate the efficiency of the Lactobacillus strains (PCS20, PCS22, PCS25, LGG, PCK9) to reduce C. jejuni K49/4 invasion into intestinal epithelial PSI cl.1 and CLAB cells as the monolayer model. The $C$. jejuni invasion rate into these cell monolayers was reduced by $90 \%$ when the probiotic bacteria where used (Fig. 2b). Thus, the competitive adhesion assays using PSI cl.1 and CLAB cell monolayers showed that addition of probiotic bacteria efficiently reduces the $C$. jejuni adherence to the surface of intestinal epithelial cells, and their invasion of these cells.

\section{Campylobacter jejuni adhesion and invasion using the polarised cell model}

The efficiency of Lactobacillus strains PCS20, PCS22, PCS25, LGG and PCK9 to impair C. jejuni K49/4 adhesion and invasion were also tested using the threedimensional functional model of the pig PSI cl.1 and chicken B1OXI polarised intestine epithelial cells. An additional file shows this in more detail (see the Additional file 1). The post-infection growth kinetics (i.e. 3, 17 and $24 \mathrm{~h}$ ) were determined for $C$. jejuni adhesion (Fig. 3) and invasion (Fig. 4). C. jejuni adhesion to PSI cl.1 cells was more pronounced, with more adhered $C$. jejuni observed $17 \mathrm{~h}$ post-infection, which then dropped off (Fig. 3a). On the other hand, there was an increase in number of $C$. jejuni on the chicken B1OXI cells from the beginning of the infection, with the highest levels reached at $24 \mathrm{~h}$ post-infection (Fig. $3 \mathrm{~b}$ ). The addition of the probiotic bacteria PCS20, PCS22, PC25 and PCK9 significantly decreased $C$. jejuni adherence to PSI cl.1 


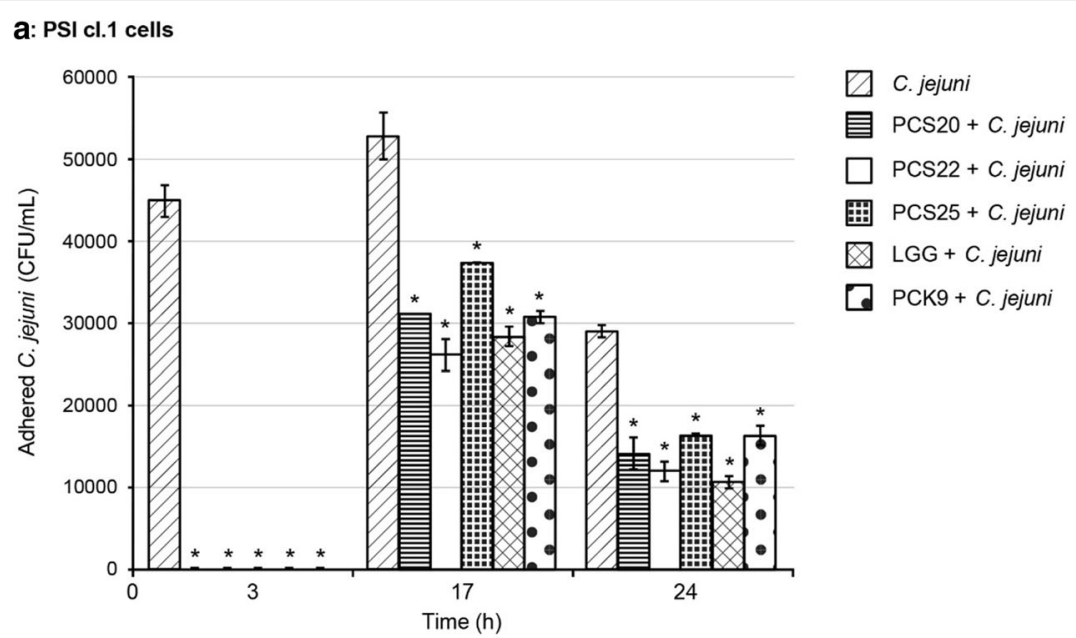

b: B10XI cells

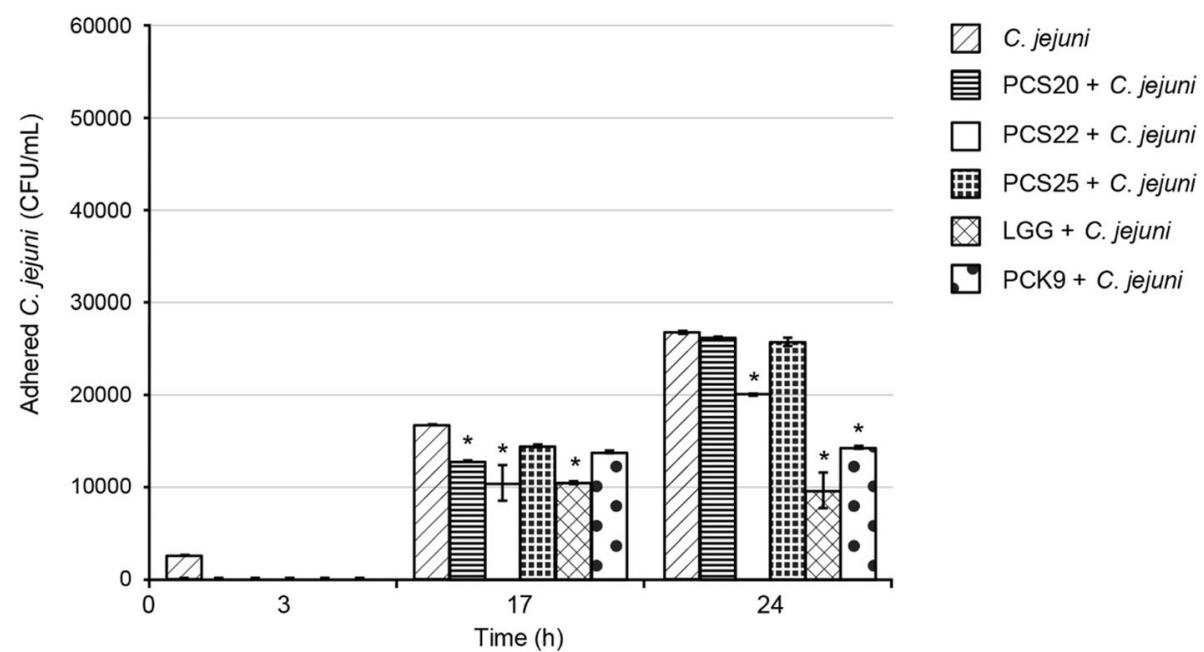

Fig. 3 Effects of the probiotic bacteria on adhesion of C. jejuni using polarised pig PSI cl.1 (a) and chicken B1OXI (b) intestine epithelial cells, after $2 \mathrm{~h}$ co-culture without and with putative probiotic bacteria. Error bars indicate the standard deviation from at least three independent experiments. Data are expressed as means \pm SD. ${ }^{*} P \leq 0.01$, versus control

and B1OXI cells early in the observation period (i.e., after $3 \mathrm{~h}$ ), compared to non-treated cells (Fig. 3). Addition of PCS20, PCS22, PCS25 and PCK9 cells also significantly decreased the number of $C$. jejuni adhered to PSI cl.1 cells after $17 \mathrm{~h}$ and $24 \mathrm{~h}$ (Fig. 3a). However, for the numbers of $C$. jejuni adhered to B1OXI cells, these remained at the control levels $24 \mathrm{~h}$ post-infection when PCS20 and PCS25 were used, and only the PCS22, LGG and PCK9 significantly reduced these numbers (Fig. 3b). The control C. jejuni invasion into PSI cl.1 cells remained constant to $24 \mathrm{~h}$, but was comparable to B1OXI cells only at $3 \mathrm{~h}$ post-infection (Fig. 4). Addition of PCS20, PCS22, PCS25 and PCK9 reduced the invasiveness of $C$. jejuni into PSI cl.1 cells to below the level of detection regardless of the time post-infection
(Fig. 4a). C. jejuni invasion into B1OXI cells was only seen at $3 \mathrm{~h}$ post-infection, and addition of PCS20, PCS22 and PCK9 significantly reduced this $C$. jejuni invasiveness (Fig. 4b). Strains PCS25 and LGG were the two most efficient strains in preventing the invasion of $C$. jejuni into B1OXI cells when compared to other strains. When these two strains were co-incubated with $C$. jejuni, no invasion into B1OXI was observed $3 \mathrm{~h}$ post-infection (Fig. 4b).

Intestinal epithelium integrity and C. jejuni translocation The efficiency of Lactobacillus strains PCS20, PCS22, PCS25, LGG and PCK9 to impair the effects to C. jejuni K49/4 on epithelial intercellular integrity were investigated. These were determined by measurements of 
a: PSI cl.1 cells

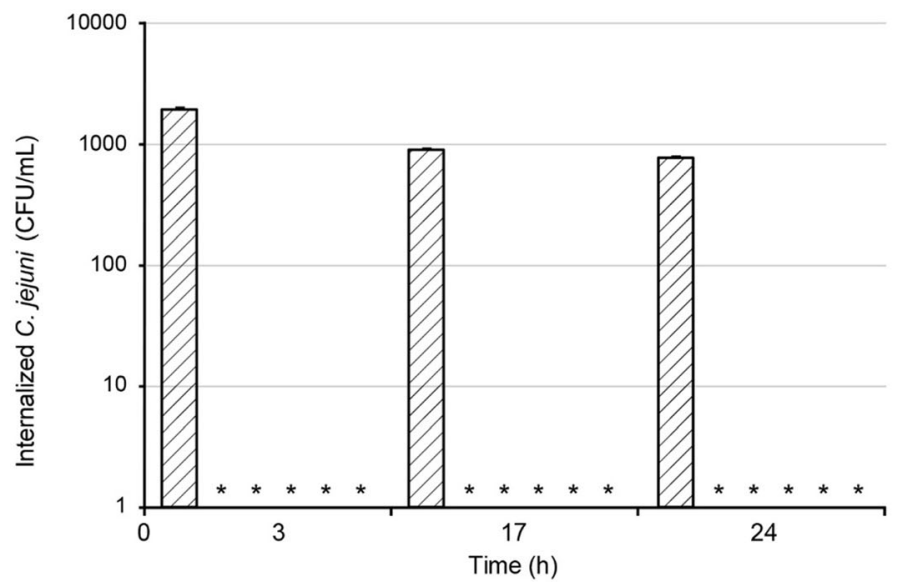

$\triangle$ C. jejuni

居 PCS $20+$ C. jejuni

PCS $22+$ C. jejuni

囲 PCS $25+C$. jejuni

Q LGG + C. jejuni

$\square$ PCK $9+$ C. jejuni

b: B10XI cells
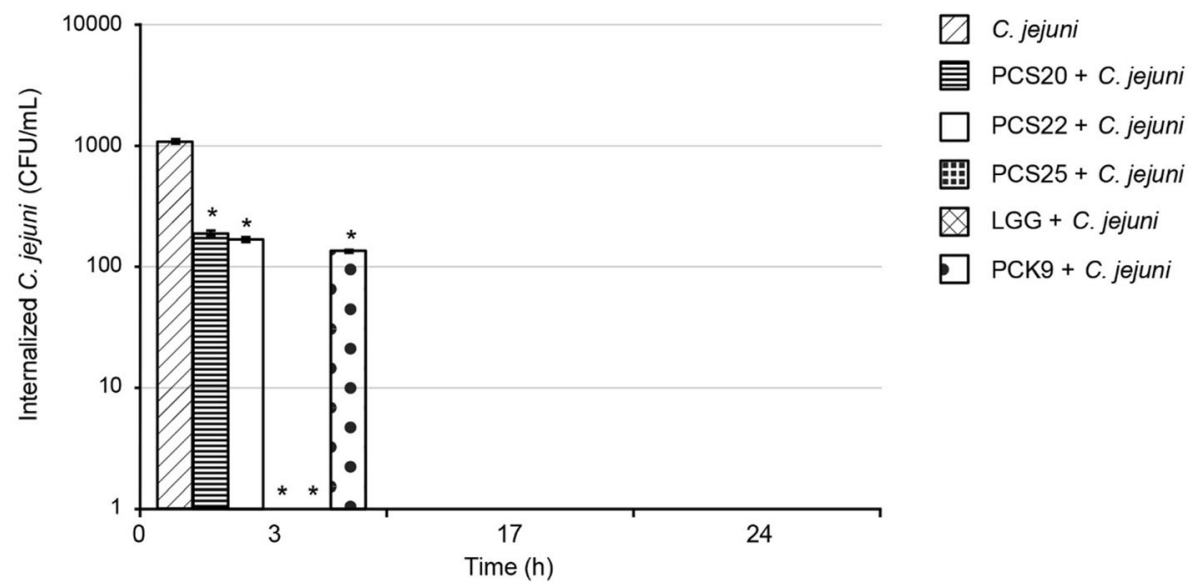
after $2 \mathrm{~h}$ co-culture without and with probiotic bacteria. Error bars indicate the standard deviation from at least three independent experiments. Data are expressed as means $\pm S D .{ }^{*} P \leq 0.01$, versus control

TEER immediately after infection of polarised PSI cl.1 and B1OXI cells, and after 3, 17 and $24 \mathrm{~h}$ post-infection.

Initially, the effects of the probiotic bacteria on epithelial intercellular integrity of the PSI cl.1 and B1OXI cells were determined. At $1 \times 10^{7} \mathrm{CFU} / \mathrm{mL}$, the probiotic bacteria generally increased the TEER of the PSI cl.1 (data not shown) and B1OXI (Fig. 5a) polarised monolayers over the first $3 \mathrm{~h}$ of exposure (except for PCS22), as compared to the control $(p<0.01)$. By $24 \mathrm{~h}$ postinfection, the TEER in the presence of the probiotic bacteria PCS20, PCS22 and PCS25 decreased to below the control value. The exceptions of LGG and PCK9 maintained significantly increased TEER to $24 \mathrm{~h}$ postinfection with the B1OXI polarised monolayer, as compared to control $(p<0.01)$ (Fig. 5a).

The C. jejuni adherence to PSI cl.1 and B1OXI (Fig. 5b) polarised cells decreased the TEER to $24 \mathrm{~h}$ post-infection.
For the B1OXI polarised cells, the addition of all of the probiotics to $C$. jejuni significantly decreased TEER in the first $3 \mathrm{~h}$ post-infection, a situation generally maintained to $24 \mathrm{~h}$ post-infection, for PCS20, PCS22 and PCS25. In contrast, addition of LGG and PCK9 resulted in increased TEER of B1OXI polarised cells beyond these first $3 \mathrm{~h}$ post-infection (Fig. 5b). Incubation of the PSI cl.1 polarised cells with $C$. jejuni caused additional decline in TEER values when compared to the probiotic bacteria only. Interestingly, no significant differences were observed for PSI cl.1 polarised cells between the probiotic strains $(p>0.01)$. The TEER of PSI cl.1 monolayers with no bacteria added was relatively constant over the $24 \mathrm{~h}$ of monitoring $\left(\approx 1850 \Omega / \mathrm{cm}^{2}\right)$.

C. jejuni K49/4 translocated to the basolateral compartment after apical infection of PSI cl.1 and B1OXI cells, as seen at $3 \mathrm{~h}$ post-infection (Fig. 6). Differences 


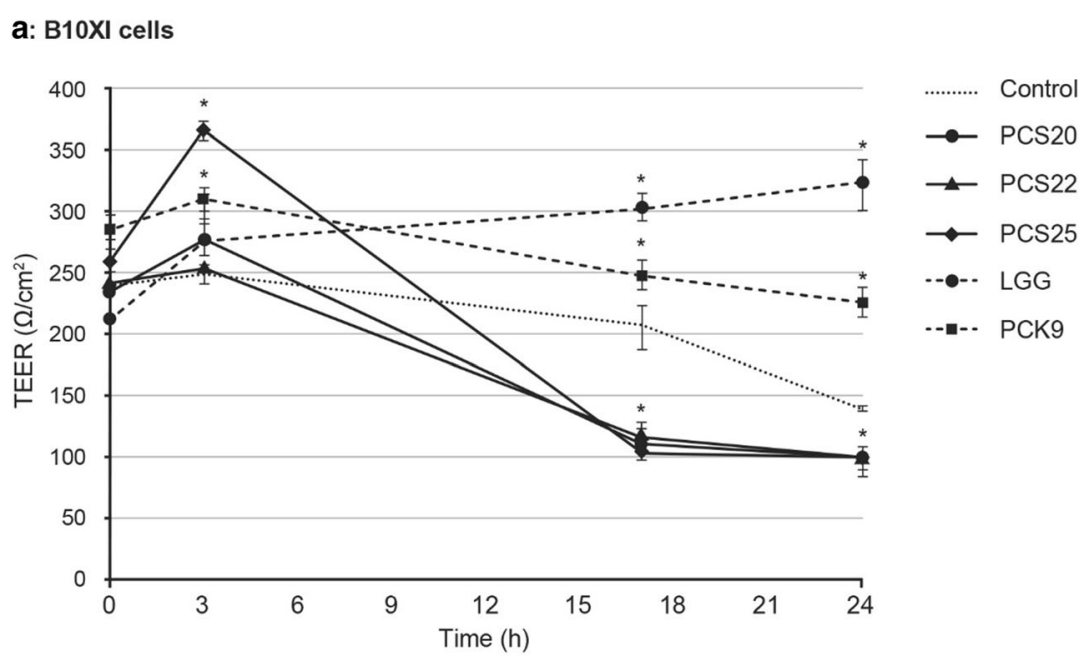

\section{b: B10XI cells}

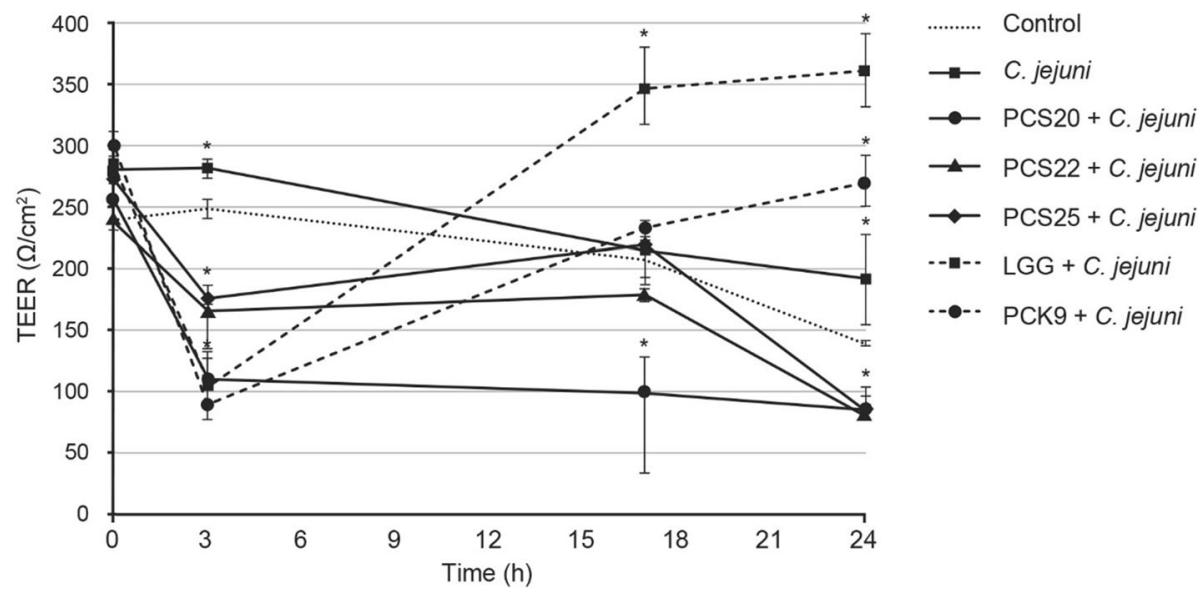

Fig. 5 Transepithelial electrical resistance (TEER). PSIc1.1 (not shown) and B1OXI cells (a and b) were seeded at $6 \times 10^{5}$ cells/well, as functional cell models using 12-well Transwell plates. As confluent monolayers, cells were exposed to the selected probiotic bacteria $\left(1 \times 10^{8} \mathrm{CFU} / \mathrm{mL}\right)$ and C. jejuni $\left(2 \times 10^{8} \mathrm{CFU} / \mathrm{mL}\right)$ for $2 \mathrm{~h}$. Error bars indicate the standard deviation from at least three independent experiments. Data are expressed as means \pm SD. ${ }^{*} P \leq 0.01$, versus control

were seen when comparing C. jejuni translocation through these PSI cl.1 and B1OXI polarised monolayers. By $24 \mathrm{~h}, 1 \times 10^{2}$ C. jejuni $\mathrm{CFU} / \mathrm{mL}$ were present in the basolateral compartment for PSI cl.1 cells (Fig. 6a). No translocated bacteria were detected after $17 \mathrm{~h}$ postinfection for B1OXI cells (Fig. 6b). At $3 \mathrm{~h}$ post-infection, addition of PCS20, PCS22, PCS25, LGG and PCK9 significantly impaired $C$. jejuni translocation to the basolateral chamber of PSI cl.1 and B1OXI cells (Fig. 6). Of note, although $C$. jejuni adhered in high numbers to PSI cl. 1 cells to $24 \mathrm{~h}$ (Fig. 3 ), the probiotic bacteria prevented C. jejuni invasion into these cells (Fig. 4), and consequently the $C$. jejuni translocation to basolateral chamber. These monolayers were not disrupted over the first $17 \mathrm{~h}$ post-infection, as was observed under the microscope. In addition, the TEER stayed relatively constant over this period, which indicated that the $C$. jejuni translocation was mostly transcellular.

\section{Discussion}

Adhesion represents a virulence factor in human/animal infections that is important for Campylobacter survival out of the host and during host-pathogen interactions. Campylobacter adhesion to epithelial cells involves contact between the bacterial and the eukaryotic cell surfaces. It is also crucial for further Campylobacter invasion of the intracellular space and traversing of the host barriers, and thus for the Campylobacter pathogenicity [3, 27]. Campylobacter spp. of different origins can adhere to and invade human, porcine and avian cell lines 


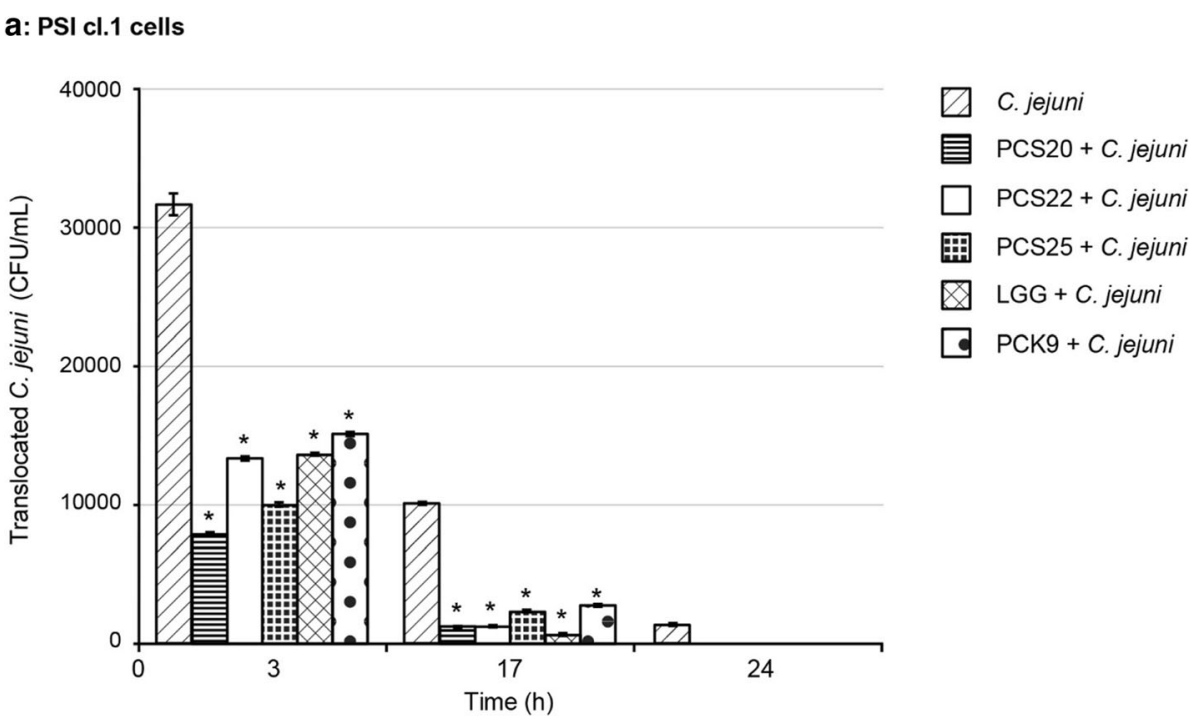

\section{b: B10XI cells}

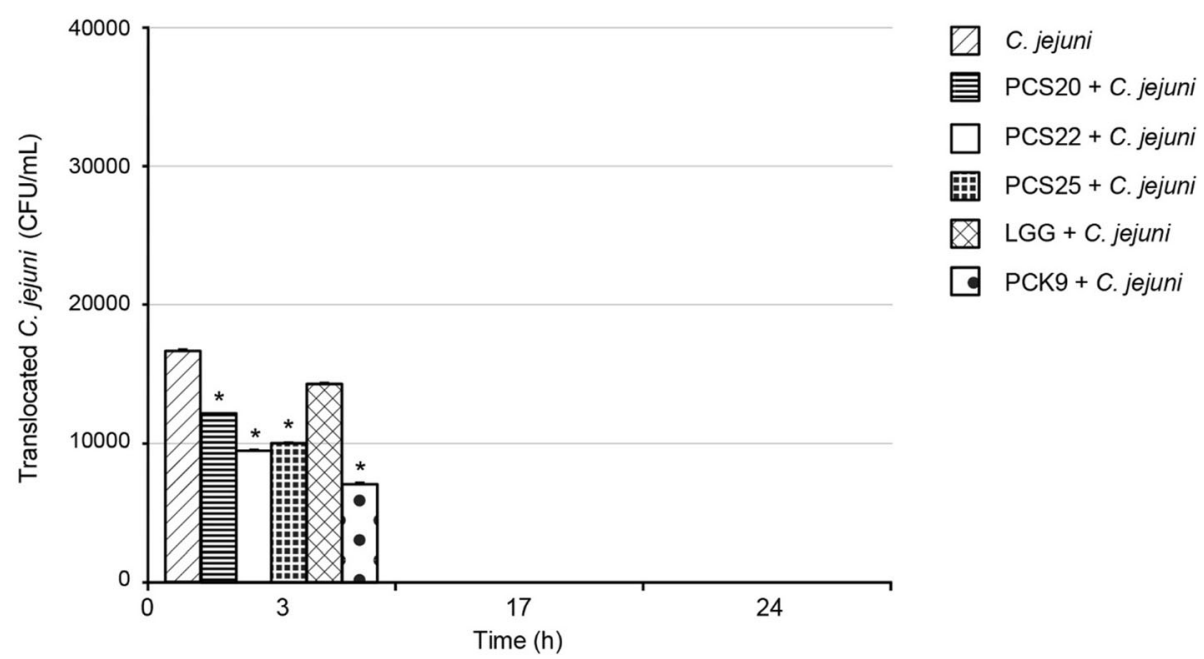

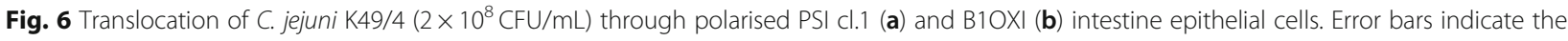
standard deviation from at least three independent experiments. Data are expressed as means \pm SD of bacteria detected in the basolateral chamber of the transwells. ${ }^{*} P \leq 0.01$, versus control

[27-32]. The data in the present study on C. jejuni adhesion to and invasion of PSI cl.1, B1OXI and CLAB cell lines are in agreement with this. Furthermore, when non-polarised PSI cl.1 and CLAB cells were used, greater C. jejuni adhesion was seen for CLAB cells, which reflects the differences in the structural and functional characteristics of the cell surface. However, when intestinal cell lines are cultivated on microporous membranes such as in transwells, they can spontaneously differentiate and polarise. In this way they serve as a much better model of the in vivo intestinal environment. Another advantage of transwells is that they can be used for studies of transport through the polarised epithelial monolayer.
In the present study, we examined the ability of selected probiotic strains to prevent and/or reduce C. jejuni K49/ 4 adhesion, invasion and translocation using different intestinal epithelial cell lines of non tumor origin, in order to stimulate more closely the host-pathogenprobiotic interactions. The cell lines were co-incubated with C. jejuni $\mathrm{K} 49 / 4$ and various probiotic strains in order to simulate a possible scenario of infection.

First, we demonstrated no cytotoxic activities of selected probiotic bacteria towards pig PSI cl.1, chicken B1OXI epithelial small intestine cells, and pig CLAB enterocytes. Our results showed that the most sensitive cell line to addition of $C$. jejuni was the PSI cl.1, while 
the B1OXI cells tolerated exposure to prolonged probiotic-pathogen interactions reflecting the pathological or commensal behaviour of C. jejuni in different intestinal epithelial cell line. Results on adhesion capacity showed that at $3 \mathrm{~h}$ post-infection, $C$. jejuni adhesion to polarised PSI cl. 1 cells was greater in comparison to that with polarised B1OXI cells, which is in agreement with earlier studies [33, 34]. The numbers of $C$. jejuni that adhered to the polarised PSI cl.1 cells decreased towards the end of observation period (i.e., $24 \mathrm{~h}$ post-infection). As suggested by Van Deun et al. (2008) this might be a colonisation strategy of Campylobacter spp. involving rapid replication in the intestine mucus followed by invasion of the intestinal epithelium in order to avoid mucosal clearance [35]. In contrast, the numbers of adhered C. jejuni increased from the beginning of the infection on B1OXI cells, which demonstrates the host-specific tropism of this pathogen. This is in agreement with other studies that have demonstrated that within an avian host, Campylobacter behave as commensals and do not proliferate intracellularly $[35,36]$. However, the differences in $C$. jejuni adhesion indicate strain-specific responses, and also different mechanisms of adhesion for these different cell lines, which is in agreement with other studies [24, 36, 37].

Furthermore, we aimed to prevent/reduce this adhesion to the non-polarised PSI cl.1 and CLAB cells and the polarised PSI cl.1 and B1OXI intestinal epithelial cells by addition of probiotics, and thus to potentially control Campylobacter contamination and/or transmission.

With the main emphasis on human health, this can be particularly effective in the first segment of the food chain, which is an animal breeding for meat production. This has become urgent because of the high Campylobacter prevalence, increased antibiotics usage and consequent bacterial resistance on livestock farms, and especially in broiler production [38]. Thus, one of the options is to reduce the prevalence of broiler flocks colonised with Campylobacter, and to reduce the intestinal Campylobacter load of the broiler chickens prior to slaughter $[1,8]$.

To avoid the selection pressure for the emergence of resistant bacteria and to avoid deleterious effects that antibiotics can have on the protective microbiota, research is ongoing into alternative strategies, including phage therapy and vaccination; however, none of these approaches have proven effective in practice to date $[7$, 39]. In our research, we have studied the use of probiotics as an alternative strategy. Probiotics are known to increase blood glucose and albumin contents which indicate a better digestion and absorption of nutrients in the broiler, they decrease blood triglycerides and cholesterol, promote the integrity of the healthy gastrointestinal barrier, and also to enhance the gut microbiota. They contribute to the general well being of the host due to symbiosis they establish within the host [18]. This might allow the prevention, and potentially the treatment, of a variety of human diseases, through delaying C. jejuni colonisation and the signal transduction that arises during $C$. jejuni infection [40, 41].

As observed, Lactobacillus spp. reduced C. jejuni adhesion to pig PSI cl.1 epithelial small intestine cells and CLAB enterocytes using a non-polarised cell model, with the greatest effects seen for $L$. rhamnosus LGG. We confirmed that the presence of these probiotic bacteria hindered the adherence of $C$. jejuni to the cell surface. We thus support the conclusion of Mohan (2015), who reported that particular probiotic strains can out-compete C. jejuni through different mechanisms of actions. Mohan (2015) particularly noted that the probiotics reached the adhesion sites more rapidly, with competitive exclusion against $C$. jejuni through occupation of the adhesion sites [42]. The present data (e.g. Figs. 2 and 3 ) show that $L$. rhamnosus LGG was the most effective among selected probiotics and reduced the most the adherence of $C$. jejuni to both polarised PSI cl.1 and B1OXI cells. This would appear to be mediated via the adherence of $L$. rhamnosus LGG to these intestine cells and its persistence there for prolonged periods after administration, as was also indicated by the study of Alander et al. (1999) [43]. In addition, while the numbers of adhered $C$. jejuni dropped towards the end of the observational period ( $24 \mathrm{~h}$ post -infection) in PSI cl 1 cells, the opposite was observed in B1OXI cells. This could reflect not only the different nature of interactions as pathogen or commensal in different host but also the different attachment capacity and affinity of probiotic strains for attachment sites. Once adhered to the host cell, $C$. jejuni can then invade the cell, and hence survive for long periods inside both phagocytes and epithelial cells $[44,45]$. This is a further important factor in disease pathogenesis, and it is mainly due to cell death and/or disruption of the mucosal barrier function, and correlates with both pathogen virulence and disease severity [19].

When the probiotic bacteria were added in the present study, C. jejuni invaded the non-polarised PSI cl.1 cells in greater numbers than for the CLAB cells, which suggests that these probiotic strains were more efficient in preventing the invasion of the CLAB cells. According to other studies and knowing that Campylobacter spp. are commensals in poultry, we hypothesised that $C$. jejuni would not invade the chicken B1OXI epithelial intestinal cells in vitro [33, 34]. The data here show that $C$. jejuni invaded polarised PSI cl.1 cells in higher numbers than for the B1OXI cells, and also persisted in the PSI cl.1 cells through the whole observation period; instead, 
there were no $C$. jejuni in the B1OXI cells $17 \mathrm{~h}$ postinfection. The host immune response greatly affects $C$. jejuni colonisation, especially in the very early phase of colonisation [35]. Taking into account that adhered $C$. jejuni persisted attached to B1OXI cells for $24 \mathrm{~h}$ while not invading intestinal epithelium implies it is not recognized as pathogenic bacterium by chicken epithelial cells and continued to replicate attached to the surface of the cells.

The extent of inhibition of $C$. jejuni invasion was dependent on the probiotic strain. Each probiotic strain prevented the invasion of PSI cl.1 cells; however, only $L$. plantarum PCS25 and L. rhamnosus LGG completely inhibited $C$. jejuni invasion of B1OXI cells. Other in vitro studies have shown that the extent of reduction in adhesion and/or invasion rates due to probiotic use is highly strain specific $[19,21,40,42]$. Campana et al. (2012) observed inhibitory activity of $L$. acidophilus ATCC4356 on C. jejuni adhesion to and invasion of Caco-2 cells [46]. More recently, Wang et al. (2014) isolated four adhesive Lactobacillus strains that inhibited $C$. jejuni adhesion to and invasion of human HT29 cells [47]. The presented data show that the invasion of intestinal cells in vitro can be completely prevented by the use of particular probiotic bacteria. Moreover, in agreement with other studies, the inhibition of $C$. jejuni invasion of intestinal epithelial cells might be attributed to competitive exclusion by the probiotic bacteria [48]. However, other mechanisms of action of probiotic bacteria in addition to competitive exclusion should be taken into account. This is particularly evident in the present study because better $C$. jejuni adhesion did not necessarily result in better invasion rates, and vice versa. In addition to different adherence properties of the probiotic bacteria to the intestinal epithelial cells in vitro, the production of various metabolites (e.g., bacteriocins) or alterations in the signalling cascades involved in the invasion should also be taken into account when interpreting these data, as these aspects are also likely to be modified by the probiotic bacteria.

Finally, the probiotic strains were tested for their efficacies for the prevention of $C$. jejuni translocation using the three-dimensional functional model of the pig (PSI cl.1) and chicken (B1OXI) polarised intestine epithelial cells. It would be reasonable to assume that prevention of $C$. jejuni adhesion to eukaryotic cells would prevent the translocation of this pathogen. Alemka et al. (2010) showed that probiotics attenuated $C$. jejuni adhesion to, invasion of, and translocation across polarised HT29MTXE12 cells, which is a sub clone of the human colon carcinoma HT29 cell line that secretes mucus [36]. Contrary to our expectation, at $3 \mathrm{~h}$ post-infection, C. jejuni efficiently translocated across the polarised chicken B1OXI intestinal cells; interestingly, the translocation level was much lower when compared to PSI cl.1 cells. Similar observations were reported by Konkel et al. (1992), who initially showed the highest rate of $C$. jejuni translocation at $4 \mathrm{~h}$ post-infection for polarised Caco-2 cells [45]. When probiotics in the present study were incubated with $C$. jejuni, the levels of translocated $C$. jejuni were similar in both PSI cl.1 and B1OXI cell lines (Fig. 6). Later, despite high levels of adhered C. jejuni (Fig. 3b), no Campylobacter spp. were detected in the basolateral chamber of the B1OXI cells (Fig. 6b) and no monolayer disruption was observed under the microscope which suggested that no translocation occurred and that $C$. jejuni did not proliferate in the basolateral chamber. The route of $C$. jejuni translocation to the basolateral chamber of transwells has been the subject of a lot of research, and some studies have described $C$. jejuni transcellular transcytosis [49], while others have implicated a paracellular route of translocation $[36,50]$. Changes in TEER of the infected PSI c1.1 cells during the first $24 \mathrm{~h}$ post-infection, and the persistence of C. jejuni in the basolateral chamber of the transwells, indicated here that $C$. jejuni used the transcellular rather than a paracellular route of translocation. There were also no correlations determined between the variations in the TEER of the cell lines and the translocation of $C$. jejuni across the polarised intestinal epithelial cell monolayers. Furthermore, an increase in TEER was observed for the polarised intestinal epithelial cell monolayers when the probiotic bacteria were co-incubated with $C$. jejuni indicating that latter contributed to the integrity of the intestinal epithelium.

\section{Conclusions}

Contrary to the acute enterocolitis caused by $C$. jejuni in humans, poultry exposed to Campylobacter show prolonged colonisation without pathological changes in the intestine or clinical signs of infection. Furthermore, despite several control measures, animals (and especially chickens) remain the most common source of Campylobacter spp. Addition of Lactobacillus spp. to animal feed might represent an effective novel strategy to reduce the prevalence of Campylobacter spp. in broiler chickens and colonisation in animals prior to slaughter.

To the best of our knowledge, the present study is the first that uses functional pig and chicken cell line models of non-tumorous origins to study the effects of probiotics on Campylobacter adhesion, invasion and translocation. Lactobacillus spp. reduced C. jejuni adhesion to PSI cl.1 pig epithelial small intestine cells and CLAB pig enterocytes as cell monolayers, and negatively affected C. jejuni invasion into these cells. Additionally, the probiotics impaired $C$. jejuni adhesion, invasion and translocation across three-dimensional functional PSI cl.1 and 
B1OXI polarised intestine epithelial cell models. When probiotics in the present study were incubated with $C$. jejuni, the levels of translocated $C$. jejuni were comparable in both used cell lines. During the first $3 \mathrm{~h}$ postinfection, $C$. jejuni more efficiently translocated across the polarised PSI cl.1 cells. Afterwards, C. jejuni did not translocate across PSI cl.1 and B1OXI cell monolayers when co-incubated with probiotics. Among selected probiotics, L. rhamnosus LGG was the strain that reduced adhesion efficacy of $C$. jejuni most significantly under co-culture conditions. We thus propose that the addition of Lactobacillus spp. to animal feed would represent an effective novel strategy to target Campylobacter adhesion to epithelial cells, prevent Campylobacter colonisation, reduce Campylobacter transmission, and finally, minimize the risk of bacterial spread to humans. Further research is necessary to clarify the mechanism(s) of these probiotic-Campylobacter interactions and to investigate specific/ effective probiotic strains for attenuation of the virulence properties and to combat C. jejuni infections.

\section{Methods}

\section{Bacterial strains and growth conditions}

Lactobacillus strains used in this study were Lactobacillus plantarum PCS20, PCS22, PCS25 (cheese isolates, from the collection of the Department of Biochemistry and Nutrition, Faculty of Medicine, University of Maribor, Slovenia), Lactobacillus rhamnosus LGG (from American Type Culture Collection; ATCC53103) and Lactobacillus plantarum PCK9 (from a cheese isolate, obtained during the European research project PathogenCombat; FP6-007081) [51]. The strains applied to the intestinal epithelial cell lines in our study were selected on the basis of previous in vitro and in vivo research. All Lactobacillus strains were previously determined for their probiotic characteristics and showed good adhesive properties to intestinal epithelial cells [52-55]. The tested strains were grown in De Man Rogosa, Sharpe (MRS) broth (Merck, Darmstadt, Germany) for $24 \mathrm{~h}$ at $37^{\circ} \mathrm{C}$, and under anaerobic conditions. The final bacterial suspensions for the competition assays contained approximately $1 \times 10^{8} \mathrm{CFU} / \mathrm{mL}$.

C. jejuni $\mathrm{K} 49 / 4$, a poultry meat isolate was grown at $42{ }^{\circ} \mathrm{C}$ microaerophilically $\left(5 \% \mathrm{O}_{2}, 10 \% \mathrm{CO}_{2}, 85 \% \mathrm{~N}_{2}\right)$ on Columbia agar (Oxoid, Hampshire, UK) supplemented with 5\% defibrinated horse blood (Oxoid, Hampshire, UK). C. jejuni were transferred to Preston broth (Oxoid) at $42{ }^{\circ} \mathrm{C}$, and grown microaerophilically for $9 \mathrm{~h}$. These $C$. jejuni cultures in exponential phase were diluted in cell culture media containing no antibiotics to approximately $2 \times 10^{8} \mathrm{CFU} / \mathrm{mL}$ and were used for cell culture assays.

\section{PSI cl.1, B10XI and CLAB cell monolayers}

The normal PSI cl.1 epithelial-derived cell line (partially differentiated cryptic enterocyte-like) was obtained from an adult pig at slaughter, as previously described [20]. These cells represent the closest model to humans in terms of genome, organ development, anatomy, physiology and metabolism of the intestinal tract, and for disease progression, and intestine-microbe interactions $[56,57]$. The B1OXI cells represent normal enterocytes of the chicken small intestine. The B1OXI cell line was developed and characterised at the University of Maribor, Slovenia, in the framework of the EU funded 'PathogenCombat' project, to build a three-dimensional functional epithelial cell model of the chicken intestine [51]. The CLAB cells are enterocytes that were obtained from an adult pig at slaughter in Slovenia and represent adult mucin secreting enterocyte-like cell line [56]. Although CLAB cells are epithelial in origin, they do not polarise in vitro [51]. These cells are of non-tumorigenic origin, which makes them more suitable as the in vitro model to study pathogen-host interactions than tumorigenic cell lines. The phenotypical and functional characterization of the cells was performed with immunocytochemistry and the search for the presence of key epithelial markers. In addition, all cell lines were tested for mycoplasma contamination prior to the experiments.

The PSI cl.1 and B1OXI cell lines can form a tightly packed epithelial barrier when grown on microporous inserts, and for this reason, they were chosen for further studies to evaluate the efficacy of the probiotics for prevention of $C$. jejuni $\mathrm{K} 49 / 4$ adhesion, invasion and translocation across polarised cell monolayers. PSI cl.1, B1OXI and CLAB cells are of non-tumorigenic origin; instead, they were isolated from dissected animal tissue using the limiting dilution technique. The functional PSI cl.1 and B1OXI intestinal cell models were developed for studies into probiotic/pathogen/gut epithelial interactions in more detail following initial screening for the efficacy of the probiotics for prevention of $C$. jejuni $\mathrm{K} 49 / 4$ adhesion and invasion on PSI cl.1 and CLAB cell monolayers.

\section{Cultivation and propagation of cell lines}

PSI cl.1, B1OXI and CLAB cell lines were grown in advanced Dulbecco's modified Eagle's medium (DMEM) (Sigma-Aldrich, Grand Island, USA), supplemented with $5 \%$ foetal calf serum (Lonza, Basel, Switzerland), 2 $\mathrm{mmol} / \mathrm{L} \mathrm{L}$-glutamine (Sigma), $100 \mathrm{U} / \mathrm{mL}$ penicillin (Sigma) and $1 \mathrm{mg} / \mathrm{mL}$ streptomycin (Fluka, Buchs, Switzerland), at $37^{\circ} \mathrm{C}$ in a humidified atmosphere of $5 \%$ $\mathrm{CO}_{2}$. To form monolayers, 96-well microplates were seeded with approximately $5.0 \times 10^{5}$ cells $/ \mathrm{mL}$ PSI cl. 1 and CLAB, and incubated for $24 \mathrm{~h}$ to reach confluence. 
Thereafter, the cultures were washed three times with phosphate-buffered saline (PBS) and cultivated in antibiotic free DMEM for the cell adhesion and invasion assays.

\section{PSI cl.1 and B1OXI polarised cell model}

To obtain polarised monolayers, PSI cl.1 or B1OXI cells were seeded on Transwell filter inserts (pore size, $0.4 \mu \mathrm{m} ; 12 \mathrm{~mm}$; Corning) that were placed into 12-well plates (22.1 mm, Corning), at a density of $1 \times 10^{5}$ cells/ $\mathrm{cm}^{2}$. The TEER was measured using an electrical resistance system (Millicell-ERS; Millipore, Bedford, MA, USA). The net TEER was corrected for background resistance by subtraction of the resistance of the microporous membranes with the cell cultures $\left(108 \Omega / \mathrm{cm}^{2}\right)$ from the resistances measured with the system. Functional polarity was established when the TEER between the apical and basolateral surfaces of the monolayers exceeded $1600 \Omega / \mathrm{cm}^{2}$ for PSI cl. 1 cells and $240 \Omega / \mathrm{cm}^{2}$ for B1OXI cells. TEER was measured before the cells reached confluence, after the addition of the bacteria to the medium (with or without gentamicin), and $24 \mathrm{~h}$ post-infection. The TEER of cell monolayers without bacteria was used as the control for each experiment.

\section{Effects of probiotic bacteria and C. jejuni K49/4 on viability of cell cultures}

To test the effects of the bacteria on the viability of the PSI cl.1, B1OXI and CLAB cell monolayers, the cells were seeded separately in microplates at a density of $6 \times$ $10^{5}$ cells/well. Later, each strain of viable probiotic bacteria $\left(1 \times 10^{8} \mathrm{CFU} / \mathrm{mL}\right)$ and C. jejuni K49/4 $\left(2 \times 10^{8}\right.$ $\mathrm{CFU} / \mathrm{mL}$ ) were added to pre-washed monolayers of the PSI cl.1, B1OXI and CLAB cells, and the cell monolayers were incubated for $24 \mathrm{~h}$ at $37^{\circ} \mathrm{C}$ in a humidified atmosphere of $5 \% \mathrm{CO}_{2}$. The 3-(4,5-dimethylthiazol-2-yl)-2,5diphenyltetrazolium bromide (MTT) colorimetric assay was used to determine cell viability, as described previously [58]. For each probiotic strain and for coincubation of $C$. jejuni with probiotic bacteria three wells were used for each replicate. The mean absorbance of the control wells containing only confluent cell culture without any bacteria was taken as $100 \%$. The percentage of metabolically active cells treated with probiotic bacteria and Campylobacter jejuni was then calculated.

\section{Cell culture assays}

\section{Adhesion, invasion, and intracellular survival of $C$. jejuni K49/4 with PSI cl.1 and CLAB cells}

Bacterial adhesion tests on PSI cl.1 and CLAB cell monolayers were carried out in 96-well tissue culture plates. After washing the cell monolayers with PBS, each of the probiotic bacteria (approximately $1 \times 10^{8} \mathrm{CFU} /$ $\mathrm{mL}$ ) were added simultaneously with C. jejuni K49/4 $\left(2 \times 10^{8} \mathrm{CFU} / \mathrm{mL}\right)$ to each well. The control wells were prepared by adding C. jejuni $\mathrm{K} 49 / 4$ to the cell monolayers. The cells were incubated at $37^{\circ} \mathrm{C}$ in $5 \% \mathrm{CO}_{2}$ for $2 \mathrm{~h}$, to allow adhesion and invasion. After washing with DMEM, DMEM containing $100 \mu \mathrm{g} / \mathrm{mL}$ gentamicin was added, to determine the number of invaded $C$. jejuni. After a 1-h incubation, the monolayers were lysed with $1 \mathrm{~mL} / \mathrm{L}(\mathrm{v} / \mathrm{v})$ Triton X-100, for $5 \mathrm{~min}$ and were serially diluted. The intracellular bacteria were determined by plate counting at $3,9,24$ and $48 \mathrm{~h}$ post-infection. The total numbers of adherent and internalised bacteria were determined simultaneously by performing the invasion assay, but without gentamicin treatment. The differences between the numbers of total and intracellular bacteria were calculated as the number of adherent $C$. jejuni cells.

\section{Adhesion, invasion, and translocation of C. jejuni K49/4 using the PSI Cl.1 and B1OXI polarised cell model}

A functional cell model using PSI cl.1 and B1OXI cells was developed to determine inhibitory effect of the probiotic bacteria on the $C$. jejuni K49/4 adhesion, invasion and translocation of $C$. jejuni to the basolateral compartment of the well. When cells were confirmed to have reached confluence using TEER $\left(>1600 \Omega / \mathrm{cm}^{2}\right.$ for PSI cl. 1 cells; $>240 \Omega / \mathrm{cm}^{2}$ for B1OXI cells), the monolayers were washed twice with $100 \mu \mathrm{L}$ DMEM without antibiotic/supplements, and infection assays were performed by seeding the bacterial inoculum of each probiotic culture (approximately $1 \times 10^{8} \mathrm{CFU} / \mathrm{mL}$ ) together with $C$. jejuni K49/4 (approximately $2 \times 10^{8} \mathrm{CFU} / \mathrm{mL}$ ) in the apical chamber. The total numbers of adhered and invaded C. jejuni K49/4 were determined at 3, 17 and 24 h postinfection after lysing the cells by addition of $500 \mu \mathrm{L}$ Triton X-100 and plating on Columbia agar plates. Bacterial count for infection of cell lines and chosen time intervals were similar as in our previous studies $[32,33]$. In addition, the numbers of translocated $C$. jejuni K49/4 were determined at the same time intervals. To investigate the effects of C. jejuni K49/4 on PSI cl.1 and B1OXI cell monolayer integrity following the infection of the cell lines, the TEER was measured at $0,3,17$, and $24 \mathrm{~h}$ post-infection. The TEER of the infected cells was compared to non-infected cells. Furthermore, the effects of co-incubation of probiotics with C. jejuni K49/ 4 were also assessed.

\section{Statistical analysis}

To define the effects of lactobacilli on C. jejuni K49/4 adhesion, data from triplicate samples from at least three independent experiments were analysed statistically with the Predictive Analytics (PASW) statistics 202 software, version 18.0 (IBM Corp., Armonk, NY, USA), for the significance of any changes in bacterial numbers. 
Statistical analyses were performed with unpaired Student's t-tests to estimate the statistical significance. All data are presented as means \pm standard deviations (error bars) of the replicate experiments. All statistical values were considered significant at $P \leq 0.01$.

\section{Supplementary information}

Supplementary information accompanies this paper at https://doi.org/10. 1186/s12917-020-2238-5.

Additional file 1. Visual scheme of experiment. We assessed the effect of different Lactobacillus strains on C. jejuni adhesion, invasion and translocation using pig (PSI) and chicken (B1OXI) enterocyte cell lines of non tumorigenic origin.

\section{Abbreviations}

B1OXI: chicken small-intestine cell line; C. jejuni: Campylobacter jejuni: DMEM: Dulbecco's modified Eagle's medium; MTT: 3-(4,5-dimethylthiazol-2yl)-2,5-diphenyltetrazolium bromide colorimetric assay; PBS: phosphatebuffered saline; PCS20, PCS22, PCS25, LGG and PCK9: Lactobacillus strains; PSI Cl.1 and CLAB: pig enterocytes; TEER: transepithelial resistance

\section{Acknowledgments}

The authors would like to dedicate this study to Professor Dr. Avrelija Cencič, former head and founder of the Department of Biochemistry and Nutrition, Faculty of Medicine, University of Maribor, Slovenia.

\section{Authors' contributions}

MŠP, AK, TL, DMT and SSM conceived the study. MŠP, AK and TL performed the experimental work with Campylobacter jejuni and cell cultures. DMT and AK helped with the analysis of the obtained results. MŠP, AK, TL, DMT and SSM interpreted the results and MŠP wrote the article. All authors read and approved the final manuscript.

\section{Funding}

The study was partially funded by the Slovenian Research Agency (Grant numbers: J4-9299, P3-0036, and J3-1762). The funders had no role in the design of the study, data collection, analyses, interpretation of data or preparation of the manuscript.

\section{Availability of data and materials}

The data that support the findings of this study are available from the corresponding author upon reasonable request.

\section{Ethics approval and consent to participate}

Ethics approval was not necessary for this research.

\section{Consent for publication}

Not applicable.

\section{Competing interests}

The authors declare that they have no competing interests.

\section{Author details \\ ${ }^{1}$ Faculty of Medicine, University of Maribor, 2000 Maribor, Slovenia. 2Department of Microbiology, Biochemistry, Molecular Biology and Biotechnology, Faculty of Agriculture and Life Science, University of Maribor, 2311 Hoče, Slovenia. ${ }^{3}$ Department of Food Science and Technology, Biotechnical Faculty, University of Ljubljana, 1000 Ljubljana, Slovenia.}

Received: 3 September 2019 Accepted: 9 January 2020

Published online: 03 February 2020

\section{References}

1. Vanmarsenille C, del Olmo ID, Elseviers J, Hassanzadeh Ghassabeh G, Moonens K, Vertommen D, et al. Nanobodies targeting conserved epitopes on the major outer membrane protein of Campylobacter as potential tools for control of Campylobacter colonization. Vet Res. 2017;48:86. https://doi. org/10.1186/s13567-017-0491-9.

2. Duarte A, Alves AC, Ferreira S, Silva F, Domingues FC. Resveratrol inclusion complexes: antibacterial and anti-biofilm activity against Campylobacter spp. and Arcobacter butzleri. Food Res Int. 2015;77:244-50.

3. Tabashsum Z, Peng M, Kahan E, Rahaman SO, Biswas D. Effect of conjugated linoleic acid overproducing Lactobacillus with berry pomace phenolic extracts on Campylobacter jejuni pathogenesis. Food Funct. 2019. https://doi.org/10.1039/c8fo01863d.

4. van Vliet AHM, Ketley JM. Pathogenesis of entric Campylobacter infection. J Appl Microbiol. 2001;90:45-56.

5. Esson D, Gupta S, Bailey D, Wigley P, Wedley A, Mather AE, et al. Identification and initial characterisation of a protein involved in Campylobacter jejuni cell shape. Microb Pathog. 2017;104:202-11.

6. Hermans D, Van Deun K, Martel A, Van Immerseel F, Messens W, HeyndrickX $\mathrm{M}$, et al. Colonization factors of Campylobacter jejuni in the chicken gut. Vet Res. 2011:42:82

7. EFSA and ECDC. The European Union summary report on trends and sources of zoonoses, zoonotic agents and food-borne outbreaks in 2016. EFSA J. 2017;15(12):228.

8. Meunier M, Guyard-Nicodéme M, Dory D, Chemaly M. Control strategies against Campylobacter at the poultry production level: biosecurity measures, feed additives and vaccination. J Appl Microbiol. 2016;120:1139-73.

9. Lin J. Novel approaches for Campylobacter control in poultry. Foodborne Pathog Dis. 2009;6:755-65.

10. Ghareeb K, Awad WA, Mohnl M, Porta R, Biarnés M, Böhm J, et al. Evaluating the efficacy of an avian-specific probiotic to reduce the colonization of Campylobacter jejuni in broiler chickens. Poult Sci. 2012;91:1825-32.

11. Kim SA, Jang MJ, Kim SY, Yang Y, Pavlidis HO, Ricke SC. Potential for prebiotics as feed additives to limit foodborne Campylobacter establishment in the poultry gastrointestinal tract. Front Microbiol. 2019;10:91. https://doi. org/10.3389/fmicb.2019.00091.

12. Hume ME. Historic perspective: prebiotics, probiotics, and other alternatives to antibiotics. Poult Sci. 2011;90:2663-9.

13. Ganan M, Silván M, Carrascosa AV, Martinez-Rodriguez AJ. Alternative strategies to use antibiotics or chemical products for controlling Campylobacter in the food chain. Food Control. 2012;24:6-14.

14. Salaheen SB, White B, Bequette BJ, Biswas D. Peanut fractions boost the growth of Lactobacillus casei that alters the interactions between Campylobacter jejuni and host epithelial cells. Food Res Int. 2014;62:1141-6.

15. Saint-Cyr MJ, Guyard-Nicodème M, Messaoudi S, Chemaly M, Cappelier J-M, Dousset $\mathrm{X}$, et al. Recent advances in screening of anti-Campylobacter activity in probiotics for use in poultry. Front Microbiol. 2016;7:553. https:// doi.org/10.3389/fmicb.2016.00553.

16. Hill C, Guarner F, Reid G, Gibson GR, Merenstein DJ, Pot B, et al. Expert consensus document: the international scientific association for probiotics and prebiotics consensus statement on the scope and appropriate use of the term probiotic. Nat Rev Gastroenterol Hepatol. 2014;11:506-14.

17. Hou C, Zeng X, Yang F, Liu H, Qiao S. Study and use of the probiotic Lactobacillus reuteri in pigs: a review. J Anim Sci Biotechnol. 2015;6(1):14.

18. Pourakbari M, Seidavi AR, Asadpour L, Martínez Marín AL. Probiotic level effects on growth performance, carcass traits, blood parameters, cecal microbiota, and immune response of broilers. An Acad Bras Ciênc. 2016: 88(2):1011-21.

19. Valeriano VDV, Balolong MP, Kang DK. Probiotic roles of Lactobacillus sp. in swine: insights from gut microbiota. J Appl Microbial. 2017;122(3):554-67.

20. Langerholc T, Maragkoudakis PA, Wollgast J, Gradišnik L, Cencič A. Novel and established intestinal cell line models - an indispensable tool in food science and nutrition. Trends Food Sci Technol. 2011;22:11-20.

21. Byrne CM, Clyne M, Bourke B. Campylobacter jejuni adhere to and invade chicken intestinal epithelial cells in vitro. Microbiol. 2007;153:561-9.

22. Wine $\mathrm{E}$, Chan VL, Sherman PM. Campylobacter jejuni mediated disruption of polarized epithelial monolayers is cell-type specific, time dependent and correlates with bacterial invasion. Pediatr Res. 2008:64:599-604.

23. Tareb R, Bernardeau M, Gueguen M, Vernoux JP. In-vitro characterization of aggregation and adhesion properties of viable and heat-killed forms of two probiotic Lactobacillus strains and interaction with foodborne zoonotic bacteria, especially Campylobacter jejuni. J Med Microbiol. 2013:62:637-49.

24. Ganan M, Martinez-Rodriguez AJ, Carrascosa AV, Vesterlund S, Salminen S, Satokari R. Interaction of Campylobacter spp. and human probiotics in chicken intestinal mucus. Zoonoses Public Health. 2013;60:141-8. 
25. Cean A, Stef L, Simiz E, Julean C, Dumitrescu G, Vasile A, Pet E, Drinceanu D, Corcionivoschi N. Effect of human isolated probiotic bacteria on preventing Campylobacter jejuni colonization of poultry. Foodborne Pathog Dis. 2015:12:122-30.

26. Johnson TJ, Shank JM, Johnson JG. Current and potential treatments for reducing Campylobacter colonization in animal hosts and disease in humans. Front Microbiol. 2017;8:487. https://doi.org/10.3389/fmicb.2017.00487.

27. Hofreuter D. Defining the metabolic requirements for the growth and colonization capacity of Campylobacter jejuni. Front Cell Infect Microbiol. 2014:4:1-19.

28. Šikić Pogačar M, Klančnik A, Smole Možina S, Cencič A. Attachment, invasion, and translocation of Campylobacter jejuni in pig small-intestinal epithelial cells. Foodborne Pathog Dis. 2010;7:589-95.

29. Biswas D, Itoh K, Sasakawa C. Uptake pathways of clinical and healthy animal isolates of Campylobacter jejuni into INT-407 cells. FEMS Immuno Med Microbiol. 2000;29:203-11.

30. Larson CL, Shah DH, Dhillon A, Call DR, Ahn S, Haldorson GJ, et al, Campylobacter jejuni invade chicken LMH cells in efficiently and stimulate differential expression of the chicken CXCLi1 and CXCLi2 cytokines. Microbiol. 2008;154:3835-47.

31. Šikić Pogačar M, Klančnik $A$, Bucar $F$, Langerholc $T$, Smole Možina $S$. Alpinia katsumadai extracts inhibit adhesion and invasion of Campylobacter jejuni in animal and human foetal small intestine cell lines. Phytother Res. 2015;29:1585-9.

32. Šikić Pogačar M, Klančnik A, Smole Možina S, Mičetić-Turk D. Prevention of Campylobacter jejuni K49/4 adhesion to porcine small intestine cell line PS cl 1 using different plant extracts. Acta Med Biotechnica. 2017;10(2):48-57.

33. Beery JT, Hugdahl MD, Doyle MP. Colonization of gastrointestinal tracts of chicks by Campylobacter jejuni. Appl Environ Microbiol. 1988;54:2365-70.

34. Meinersmann RJ, Helsel LO, Fields PI, Hiett KL. Discrimination of Campylobacter jejuni isolates by fla gene sequencing. J Clin Microbiol. 1997;35:2810-4

35. Van Deun K, Pasmans F, Ducatelle R, Flahou B, Vissenberg K, Martel A, Van den Broeck W, Van Immerseel F, Haesebrouck F. Colonization strategy of Campylobacter jejuni results in persistent infection of the chicken gut. Vet Microbiol. 2008;130:285-97.

36. Alemka A, Clyne M, Shanahan F, Tompkins T, Corcionivoschi N, Bourke B. Probiotic colonization of the adherent mucus layer of HT29MTXE12 cells attenuates Campylobacter jejuni virulence properties. Infect Immun. 2010;78:2812-22.

37. Collado MC, Meriluoto J, Salminen S. Adhesion and aggregation properties of probiotic and pathogen strains. Eur Food Res Technol. 2008;226:1065-73.

38. Lagha AB, Haas B, Gottschalk M, Grenier D. Antimicrobial potential of bacteriocins in poultry and swine production. Vet Res. 2017;48:22. https:// doi.org/10.1186/s13567-017-0425-6.

39. Castanon JIR. History of the use of antibiotic as growth promotes in European poultry feeds. Poult Sci. 2007;86:2466-71.

40. Arsi K, Donoghue AM, Woo-Ming A, Blore PJ, Donoghue DJ. Intracloacal inoculation, an effective screening method for determining the efficacy of probiotic bacterial isolates against Campylobacter colonization in broiler chickens. J Food Prot. 2015;78:209-13.

41. Hossain M, Sadekuzzaman IM, Ha S-D. Probiotics as potential alternative biocontrol agents in the agriculture and food industried: a review. Food Res Int. 2017;100:63-73.

42. Mohan V. The role of probiotics in the inhibition of Campylobacter jejuni colonization and virulence attenuation. Eur J Clin Microbiol Infect Dis. 2015;34:1503-13.

43. Alander M, Satokari R, Korpela R, Saxelin M, Vilpponen-Salmela T, MattilaSandholm T, et al. Persistence of colonization of human colonic mucosa by a probiotic strain, Lactobacillus rhamnosus $\mathrm{GG}$, after oral consumption. Appl Environ Microbiol. 1999;65:351-4.

44. Šikić Pogačar $M$, Rubeša Mihaljević $R$, Klančnik $A$, Brumini $G$, Abram $M$, Smole Možina S. Survival of stress exposed Campylobacter jejuni in the murine macrophage J774 cell line. Int J Food Microbiol. 2009;129:68-73.

45. Konkel ME, Hayes SF, Joens LA, Cieplak W Jr. Characteristics of the internalization and intracellular survival of Campylobacter jejuni in human epithelial cultures. Microb Pathog. 1992;13:357-70.

46. Campana R, Federici S, Ciandrini E, Baffone W. Antagonistic activity of Lactobacillus acidophilus ATCC4356 on the growth and adhesion/ invasion characteristics of human Campylobacter jejuni. Curr Microbiol. 2012;64:371-8.
47. Wang G, Zhao Y, Tian F, Jin X, Chen H, Liu X, et al. Screening of adhesive lactobacilli with antagonistic activity against Campylobacter jejuni. Food Control. 2014;44:49-57.

48. Sherman PM, Johnson-Henry KC, Yeung HP, Ngo PS, Goulet J, Tompkins TA. Probiotics reduce enterohemorrhagic Escherichia coli O157:H7 and enteropathogenic E. coli O127:H6 - induced changes in polarized T84 epithelial cell monolayers by reducing bacterial adhesion and cytoskeletal rearrangements. Infect Immun. 2005;73:5138-88.

49. Bras AM, Ketley MJ. Transcellular translocation of Campylobacter jejuni across human polarized epithelial monolayers. FEMS Microbiol Lett. 1999;179:209-15.

50. Boehm M, Hoy B, Rohde M, Teqtmeyer N, Baek KT, Oyarzabal OA, Brøndsted L, Wessler S, Backert S. Rapid paracellular transmigration of Campylobacter jejuni across polarized epithelial cells without affecting TER: role of proteolytic-active HtrA cleaving E-cadherin but not fibronectin. Gut Pathog. 2012;4:3. https://doi.org/10.1186/1757-4749-4-3.

51. Cencič A, Langerholc T. Functional cell models of the gut and their applications in food microbiology. Int J Food Microbiol. 2010;141:S4-S14. https://doi.org/10.1016/j.jfoodmicro.2010.03.026.

52. Gorenjak M, Gradišnik L, Trapečar M, Pistello M, Pinto Kozmus C, Škorjanc D, et al. Improvement of lipid profile by probiotic/protective cultures: study in a non-carcinogenic small intestinal cell model. New Microbiol. 2014;37:51-64.

53. Botić T, Klingberg D, Weingartl $\mathrm{H}$, Cencic A. A novel eukaryotic cell culture model to study antiviral activity of potential probiotic bacteria. Int J Food Microbiol. 2007:115:227-34.

54. Nissen L, Chingwaru W, Sgorbati B, Biavati B, Cencič A. Gut health promoting activity of new putative probiotic/protective Lactobacillus spp. strains: a functional study in the small intestinal cell model. Int J Food Microbiol. 2009;135:288-94.

55. Trapečar M, Goropevšek A, Gorenjak M, Gradišnik L, Slak Rupnik M. CoCulture Model of the developing small intestine offers new insight in the early immunomodulation of enterocytes and macrophages by Lactobacillus spp. through STAT1 and NF-kB p65 translocation. PLoS ONE. 2014;9(1): e86297. https://doi.org/10.1371/journal.pone.0086297.

56. Lunney JK. Advances in swine biomedical model genomics. Int J Biol Sci. 1997;3:179-84.

57. Pipenbaher N, Moeller PL, Dolinšek J, Jakobsen M, Weingartl H, Cencič A. Nitric oxide (NO) production in mammalian non-tumorigenic epithelial cells of the small intestine and macrophages induced by individual strains of lactobacilli and bifidobacteria. Int Dairy J. 2009;19:166-71.

58. Mossmann T. Rapid colorimetric assay for cellular growth and survival: application to proliferation and cytotoxicity assays. J Immunol Methods. 1983;6:55-63. https://doi.org/10.1016/0022-1759(83)90303-4.

\section{Publisher's Note}

Springer Nature remains neutral with regard to jurisdictional claims in published maps and institutional affiliations.

\section{Ready to submit your research? Choose BMC and benefit from:}

- fast, convenient online submission

- thorough peer review by experienced researchers in your field

- rapid publication on acceptance

- support for research data, including large and complex data types

- gold Open Access which fosters wider collaboration and increased citations

- maximum visibility for your research: over $100 \mathrm{M}$ website views per year

At $\mathrm{BMC}$, research is always in progress.

Learn more biomedcentral.com/submissions 